\title{
MORPHOLOGICAL TAPHONOMIC TRANSFORMATIONS OF FOSSIL BONES IN CONTINENTAL ENVIRONMENTS, AND REPERCUSSIONS ON THEIR CHEMICAL COMPOSITION
}

\begin{abstract}
Y. FERNÁNDEZ-JALV@, ${ }^{1}$ B. SÁNCHEZ-CHILLÓN,${ }^{1}$ P. ANDREWS, ${ }^{2}$ S. FERNÁNDEZ-LóPEZ $Z^{3}$ and L. ALCALÁ MARTÍNEZ ${ }^{1}$

${ }^{1}$ Museo Nacional de Ciencias Naturales (CSIC), José Gutiérrez Abascal, 2. 28006-Madrid, Spain

${ }^{2}$ The Natiral History Museum, Cromwell Road, London SW7-SBD, UK

${ }^{3}$ Dept. Paleontologia, Facultad de Geologia (UCM), Ciudad Universitaria sin, 28040-Madrid, Spain

The aim of this paper is to provide a summary of structural or surface medifications of vertebrate bone remains in continental palaeenvironments that mave repercussions on their chemical composition. Both betore and atter burial, a different set of physical, chemical and biological agencies may produce modifications of the bone morphological structure and or bone chemical composition. Several of these morphological modifications are diagnostic of particular agents, which otherwise may net be noticed or identified in a ssil association. In rder to understand diagenesis, those events that occurred be re final burial have to be considered, as they may strongly modify the bone morphological structure and influence post-burial changes.
\end{abstract}

KEYW R DS. TAPHONOMY, SURFACE BONE MODIFICATIONS, DIAGENESIS, CHEMICAL COMPOSITION, PRE-BURIAL, POST-BURIAL

BONE/TOOTH SURFACE TRANSFORMATIONS AND ASSOCIATE CHEMICAL MODIFICATIONS: A REVIEW

Several taphonomic agents may alter the surface stucture of bone, dentine or enamel, as well as their molecular chemical composition. Vertebrate remains may be previously exposed on the ground and be affected by agents before burial, which are common in continental palaeoenvironments. Vertebrates, however, may directly be buried, even alive (e.g., catastrophic events or burials), and may only be affected by fossildiagenetic agents. Later on, fossils are mostly subject to slow mineral and organic transformations and loss, and thus far also to some physical structural changes (diagenetic fractures and compressions, but also recrystallizations, etc.). In continental environments, erosion is frequent and taphonomic re-elaboration or reworking (i.e., exhumation) may occur, exhuming fossils that are exposed again to sub-aerial agents more than once. All of these steps need to be studied to know the historical succession of events in a particular fossil assemblage, to increase knowledge about fossilization processes and environments of fossilization, and to understand the site formation (the time and space congruence between fossils and between fossil-sediment). The following taphonomic agents (both before burial-biostratinamic-and after-fossildiagenetic) are some of the most frequent surface alterative agents, and those for which changes in chemical composition have been observed or may be expected. 

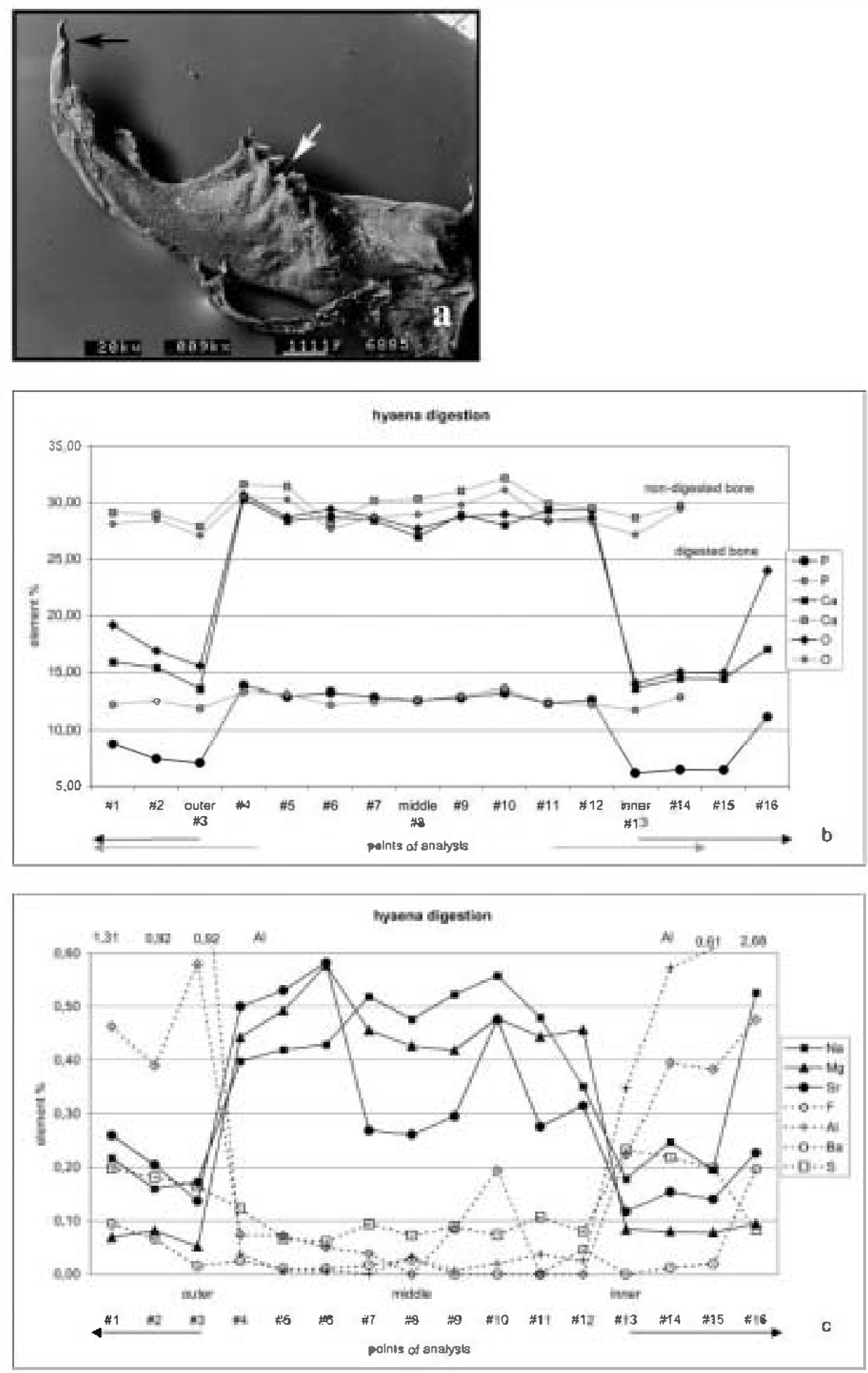
Predation/scavenging Predation, or scavenging, is the most frequent taphonomic agent that may produce bone assemblages, and one of the earliest processes that can be recognized during biostratinomic stages (Andrews 1990). Vertebrate individuals or remains may be ingested and digested by predators with resulting bone surface modifications, apart from breakage (Denys 1985; Andrews 1990). Crocodiles, hyaenids, canids, felids, mustelids, viverrids, vultures, owls and diurnal birds of prey, as well as humans, produce characteristic modifications to ingested bones during ingestion and after digestion. According to the type of predator/scavenger, related to its prey size, different sets of modifications can be recognized on small and large mammal prey bones (Hill 1979; Fisher 1981; Haynes 1983; Andrews 1990; Berger and Clarke 1995; Crandall and Stahl 1995; Selvaggio and Wilder 2001).

Grades of digestion, and also breakage and anatomical element representation, vary from nocturnal owls at one end of the scale to mammalian carnivores, humans and crocodiles at the other. These differences seem to be in agreement with degrees of acidity of the stomach gastric juices (Mayhew 1977), time of digestion and enzymatic activity (Denys et al. 1995). Values of $\mathrm{pH}$ in owls range between 2.5 and 2.2, while in falcons and hawks $\mathrm{pH}$ varies between 1.8 and 1.3 (Duke et al. 1975). Crocodiles produce one of the most extreme digestion effects (Fisher 1981; Andrews and Fernández-Jalvo 1998), more extreme than mammalian carnivores and humans, with a measured $\mathrm{pH}$ of 1.2 (Diefenbach 1975). Digestion is selective and sequential in its action. Epiphyses, salient angles and broken edges are more strongly affected than diaphysis or flat surfaces, and enamel is affected earlier and more intensively than dentine or bone (Fig. 1 (a)). Apart from morphological structural modifications, digestion also produces changes in chemical composition. Differences between chemical values of digested and non-digested small mammal bones have been observed by Dauphin et al. (1988), including changes in P, Ca and other minor elements ( $\mathrm{Sr}, \mathrm{Mg}, \mathrm{F}, \mathrm{S}, \mathrm{Cl}, \mathrm{Zn}, \mathrm{Al}, \mathrm{Ba}$ and $\mathrm{Na}$ ). Modifications in chemical composition resulting from analyses on fossil small mammals of Olduvai Bed I have been observed to be influenced by digestion effects (Denys et $\boldsymbol{a l}$. 1996). Ca, $\mathrm{P}$ and $\mathrm{S}$ are the best to discriminate the effects of digestion (Dauphin et al. 1988) and analyses carried out on the prey bones of different categories of predators show clear compositional differences related to the intensity of digestion (Dauphin et al. 1997).

Until recently, nothing was known about the changes in the chemical composition of vertebrate bones caused by digestion by large carnivores. To investigate this, we performed a

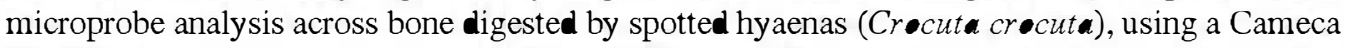
SX-50 electron microprobe at the Natural History Museum (London). Sample preparation involved a transversal cut of the bone and embedding the specimen in epoxy resin (Scandiplast).

Figure 1 (-pposite) The effects of digestion. (a) A scanning electron microphotoraph of Murinae mandible that has been very hervily digested by crocodiles (specimen from D. C. Fisher's collection). Note the curled aspect of the inciser tip (black arrow) due the complete loss of enmel. (b) A microprobe chemical nalysis of mammalian

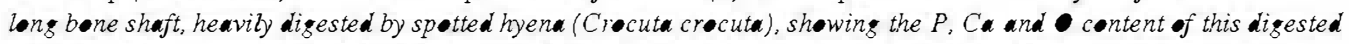
bone (in black). compared with that of non-digested bone (in grey). Analyses were performed along transversal sections of these bones, with numbers 1-3 performed n the uter side of the digested bone fragment, numbers 13-16 - $n$ the inner side of the bone (the marrow covity side), and numbers 4-12 performed in the middle part of the crosssection. For comparison, in grey, the figure shows identical analyses of these three elements on the non-digested long bone shaft, with points $1-4$ and 11-14 being the external walls of the shaft bone, and 5-1 the middle part of the cross-section. (c) The results for various chemical elements, showing two main patterns. Some elements (in black) follow similar tendency as $P$, Cand (reduction b b the inside and the atside), while some thers (empty symbols and dotted lines) follow the pposite tendency (an increment in the content o b the inside and the utside). 
The bone section was polished using a final diamond paste size of $\mathbf{0 . 2 5} \mu \mathrm{m}$. The sputtered carbon coat was kept to a minimum thickness (approximately $400 \AA$ ) in order to reduce background levels in the X-ray spectra. A cobalt sample provided the instrument calibration, and the input count rate from Co metal was adjusted to a level of 3500 counts s ${ }^{-1}$. Measurements were made using a live time of 100 or $200 \mathrm{~s}$. The analysis conditions were $15 \mathrm{kV}$ accelerating voltage, $20 \mathrm{nA}$ current and either $5 \mu \mathrm{m}$ or $20 \mu \mathrm{m}$ diameter spot size. All data were corrected using a $\rho \times f z$ matrix correction program. The results of the microprobe analyses are shown in Figures 1 (b) and (c). The analyses run along the ransversal section of the bone. In Figure 1 (b), the results from the digested bone (in black) are compared with a non-digested bone (in grey). This comparison shows differences in chemical element composition at the external walls of the digested bone in areas that are consistently homogeneous in the nondigested bone. Note also that the non-digested bone shows values of element content that are similar to those of the middle or internal part of the digested bone. The chemical composition across the bone section seems to provide two patterns of chemical element modification (Fig. 1 (c)). These results confirm that $\mathrm{Ca}, \mathrm{P}$ and also 1 are the best to discriminate digestion. A similar pattern or tendency is also followed by $\mathrm{Na}, \mathrm{Mg}$ and $\mathrm{Sr}$, in contrast to F, A1, Ba, S, Si and $\mathrm{Fe}$, which have the opposite tendency. Microprobe analysis of rare earth elements and minor elements provides a good resolution with which to detect differences related to diagenetic environments (Denys et al. 1996).

Non-predatory animal modification There are many other animals that may alter bone structure for purposes that are other than nutritional; for example, some rodents and herbivores may chew dried and weathere bones. The former animals, and especially porcupines, chew bones to wear down their ever-growing incisors (Brain 1981). Herbivores such as deer (Sutcliffe 1973), sheep (Brothwell 1976), giraffes, antelopes and cows (Sutcliffe 1973), chew bones to ingest minerals that are deficient in their diet, and rodents may also have the same need (Laudet and Fosse 2001). Chemical analyses have not been carried out on bones affected by these agents, although slight changes are expected due to the saliva enzymatic activity in herbivores. Bacterial decay (Bell et al. 1996; Davis and Briggs 1998) or the destruction of soft parts by insect action (Ellison 1990; Haskell et al. 1997) are ubiquitous processes that may physically affect hard tissues after months of activity.

Lichens, alga and fungi Metabolic activity by lichens is likely to produce chemical changes on bone colonize by lichens. The effects of lichens are associated with open-air environments, and have also been seen to affect the bone tissue structure (this has been observed on some of our experimental bones, but not yet reported). With some exceptions, algae are associated with oxidizing environments, either sub-aerial or sub-aquatic. One of us (YFJ) has analysed modern bones derived from a fluvial environment, which were covere by linearly arranged microscopic perforations that still contained diatoms. These diatoms were covered by a viscous mucilage, which could have a corrosive acid component (Bodén 1988), although this hypothesis has not been tested.

Fungi may act in open-air or sub-aquatic conditions, and in already buried environments. Wedl (1864) observed thin tunnels ( $8 \mu \mathrm{m}$ in diameter) affecting the dentine and the cement of some teeth that had been immersed in un reated water for several days. Marchiafava et al. (1974) observed well defined and calcified walls and tunnels, and could isolate some fungi, identified as genus Mucr, that may metabolize phosphates from the bone. Hackett (1981) could also isolate some burrowing fungi, identified as Fusarium sp., from bone, and described centrifugal tunnels as produced by fungi (similar to those formerly reported by Wedl 1864). Similar 
tunnelling has also been reported on bones from the Overton Down experimental earthwork, 32 years after burial. This was attributed to unidentified species of fungus (Armour-Chelu and Andrews 1996; see Fig. 11.16 for the tunnels and Fig. 11.17 for the fungal hyphae). This modification is different from linear, budded and lamellate tunnels, which were considered by Hackett as the result of bacterial activity. However, not all fungi produce perforations. Piepenbrink (1989) has proposed that these micro-organisms may segregate a substance and dissolve the osseous matrix (both organic and mineral). Grupe and Pipenbrink (1989) considered that chemical elements such as $\mathrm{Sr}, \mathrm{Zn}, \mathrm{Ba}$ or $\mathrm{Mg}$ (elements frequently used for dietary studies) can be introduced by fungi from the external environment. Child and Pollard (1990) detected 144 micro-organisms and 41 bacteriae that may, respectively, use collagen and D-aspartic acid as their only source of nitrogen (see also Hedges et al. 1995; Trueman and Martill 2002).

Weathering Alterations produced by sub-aerial weathering are reported as ranging from slight cracking and splitting of the bone surface in the early stages, to heavy cracking and deep splitting of the bone surface and overlying exfoliation in the later stages of weathering. Modifications produced on large mammal bones by exposure to weathering in African environments have been characterized by Behrensmeyer (1978), who distinguished six stages of weathering, from - (absent) to 5 (exreme). Bones become extremely fragile in the later stages of weathering, and may be completely destroye as the bone structure and consistency is lost. In contrast, Tappen (1994) observed almost no damage on elephant bones from tropical climates after 10 years of exposure. Small mammal bones exposed to weathering were studied by Andrews (1990), and large mammal bones were examined by Andrews and Armour-Chelu (1998), both in European temperate climates. Behrensmeyer (1978) proposed that sub-aerial weathering is the result of changes in temperature and humidity. But it has also been suggested by Bromage (1985) and Tuross et al. (1989a) that UV rays are responsible for breaking down collagen fibres, and then producing the characteristic splitting and the cracked bone surface. One of us (Andrews, in preparation) has observed the dispersal of and modifications to a modern carcass in the desert near Abu Dhabi (United Arab Emirates). Some ribs were observed to be partly buried in the sand, showing, after several years, a clear line marking the limit between the exposed side of the rib, which was whitened, and the covered area, which had a brownish colour. The sand could protect the rib from direct exposure to the sun, but not from changes in temperature and humidity. It is his view also that it is exposure to UV rays that produces the weathering characteristics reported by Behrensmeyer (1978), and Andrews (1990) also distinguishes this type of weathering at the surface from subsurface weathering, where bones are protected from UV radiation by vegetation or by burial in biologically active soils. Chemical studies of modern and fossil bone remains exposed on the ground have shown relevant chemical and structural changes---especially in the strontium content, which increases with weathering-as well as crystallographic alterations and protein degradation (Tuross et al. 1989a,b). Once chemical changes are known to take place when bones are weathered, the next step, as Sillen (1992) suggests, should be to investigate the amount of biological (organic content) ransformation that has taken place during the different stages of weathering.

\section{Post-burial}

Some of the agents described in previous subsections may also act after burial. This is the case for insects, fungi, bacteriae and natural combustion phenomena. In the following subsections, we will describe other agents that may act on bones after burial. 
Soil corrosion, and the depesition and burial envirenment Soil corrosion may affect bones on the ground and after burial. Bones can be corroded in contact with sediments below $\mathrm{pH} 4$ (Andrews 1990). We have found that highly alkaline sediments may also corrode bone tissues during fossilization. Experimental work to reproduce bone surface modifications observed on fossils from caves in Atapuerca, Spain (Fernández-Jalvo 1995) and from alkaline volcanic ashes in Olduvai, Tanzania (Fernández-Jalvo et al. 1998) have been performed with small mammal bones (Fernández-Jalvo 1992). Recently, these experiments have been extended to human teeth. Three pairs of human teeth were immersed in six tubes, each one containing $15 \mathrm{ml}$ of $1 \mathrm{M} \mathrm{HCl}(\mathrm{pH} \mathrm{1.07)}$ ), for periods of 15 minutes, 40 minutes and 60 minutes. Five pairs of teeth were also immersed in separate tubes containing $15 \mathrm{ml}$ of $1 \mathrm{M} \mathrm{KOH} \mathrm{(pH} \mathrm{14),} \mathrm{and} \mathrm{exposed}$ for 60 minutes, 12 hours, 24 hours, 48 hours and 72 hours. Because this second set of teeth needed to be immersed for a long period, a shaking bath was used to avoid sedimentation and to maintain the properties of the solution. The shaking bath was settled at $25^{\circ} \mathrm{C}$ in a constant mild movement. Three teeth were kept as control specimens. Teeth from the $\mathrm{HCl}$ and $\mathrm{KOH}$ solutions were rinsed five times in distilled water (in new separate tubes) and then left in distilled water overnight to stop the reaction. None of the teeth showed pathologies. Isotopic chemical analyses are currently in progress.

A pattern emerges from these experiments. Sediments with a highly alkaline $\mathrm{pH}$ value produce desquamation, a peeling off of the surface, or the detachment of a layer of scaly fragments, in the outer bone layers (Fig. 2 (a)). Dentine and tooth roots are also affected, showing a surface mosaic cracking (Figs 2 (b) and (f)). Teeth immersed in $\mathrm{K} \mathbf{O H}$ solutions show modifications only after 48 and 72 hours (Fig. 2 (f)), indicating that this is a long-term and slow process. Highly alkaline environments predominantly alter the most organic components (bone, dentine and tooth roots). Enamel is apparently not modified. This may suggest that collagen is the main component affected by exposure to highly alkaline environments over a long period of time. The opposite occurs in acid environments: it is already evident that enamel is heavily damaged and corroded (Figs 2 (c), (d) and (e)) after 1 minute, while roots and dentine show a lower degree of corrosion, or none at all. In the case of rodents, the enamel, which forms a thinner layer, has been eaten away after 1 minute (Figs 2 (c) and (d)), which shows strong similarities with the effects of digestion by crocodiles (see Fig. 1 (a)). Extremely acidic chemical environments alter the most mineralized tissues (the enamel) most greatly, as has been found for the buried bones from the experimental earthwork at Overton Down (Armour-Chelu and Andrews 1996).

Rœ^ts Root-marking on bone surfaces has been frequently observed but never chemically studied. Water charged in mineral nutrients (mainly phosphorous, but also zinc, manganese and copper) is absorbed by roots from the soil, through the degradation and breakdown of organic and inorganic matter, randomly affecting bone, dentine and enamel (Sanchez et al. 1997), in either modern or fossil bones. The symbiotic association between roots and fungi (Mycorrizae) or bacteriae (Rhizobium) is important for plant growth, and is involved in the nitrogen fixing process. Apart from some original chemical element loss from the bone tissues by root-fungi or root-bacteriae metabolism, structural damage is produced by root marking, which increases bone porosity.

Reworking or re-elaboration processes Exhumation may mix fossils with more recent remains or older fossils in a more modern sedimentary unit (Fernández-López 1991). Vertebrate fossil remains are exposed to sub-aerial agents, but the effects may differ from those reported 


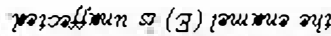

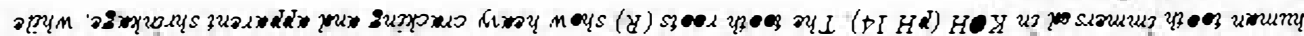

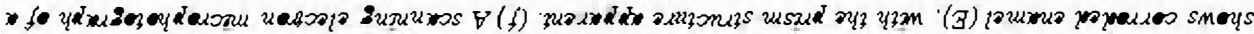

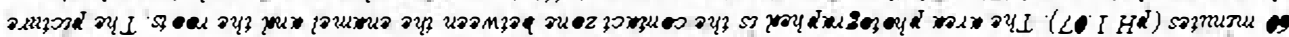

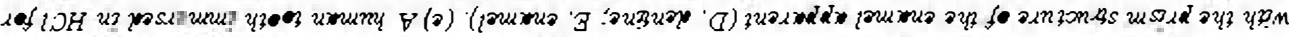

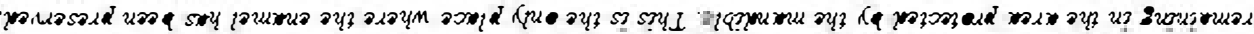

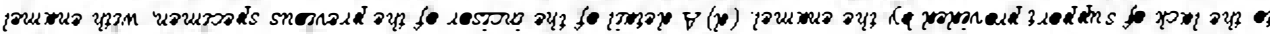

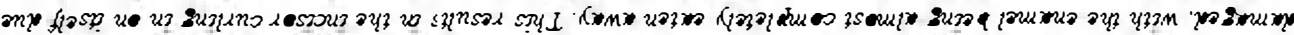
(in w y $S$ (

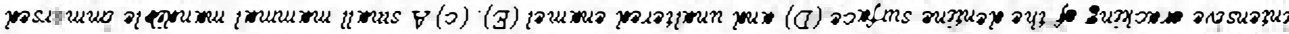

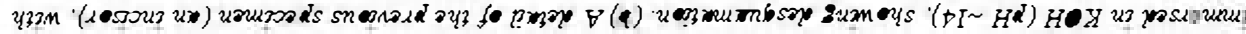

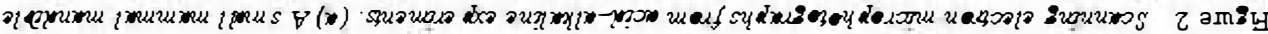
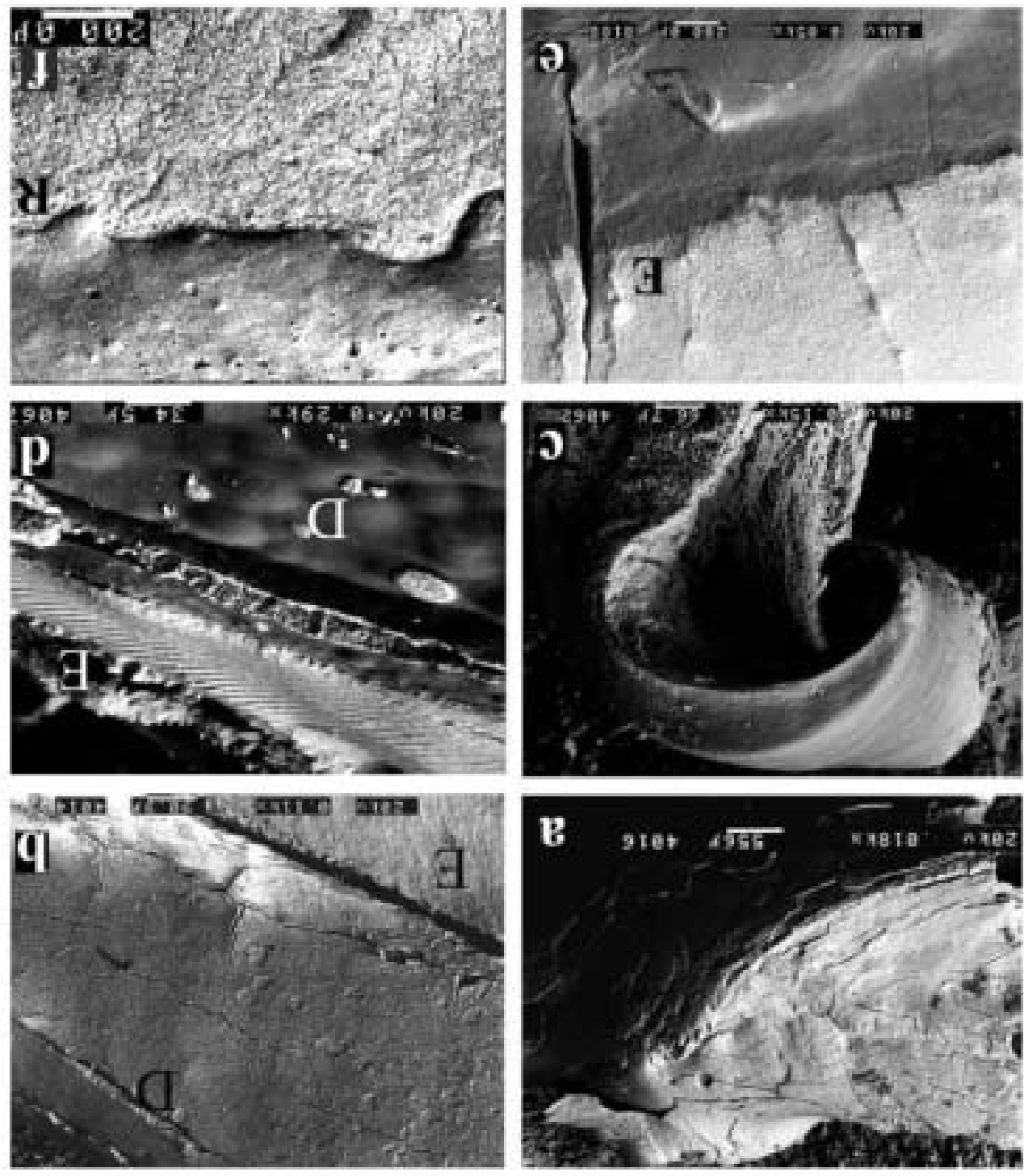
for modern and fresh bones. For instance, the effects of water-sediment abrasion are more intense when acting on fossil bones than on fresh bones (Fernández-Jalvo and Andrews 1992). Roots act also on fossils, etching their surface, but probably providing different changes in chemical composition, compared to fresh bones. New processes of dissolution, mineral replacement, recrystallization and mineral neo-formation, as well as the action of burrowing organisms, are the main modifications produced on reworked fossils. Nothing has been reported about reworked vertebrate fossils being affected by weathering, but certainly the response of fossils to subaerial agents after exhumation may be different, as may also occur in the case of soil corrosion.

\section{ACKNOWLEDGEMENTS}

The authors are grateful to C. Denys for comments on the manuscript. This work has been funded by the projects BTE2000-1309 (DGI), BTE2000-1148 (DGI) and DGESIC (PB980691-C03-01).

\section{REFERENCES}

Andrews, P., 1990, whs, caves and fossils, Natural History Museum Publications, London.

Andrews, P., and Armour-Chelu, M., 1998, Taphonomic observations on a surface bone assemblage in a temperate environment, Bulletin de la Société Gélogique de France, 169, 433-42.

Andrews, P., and Fernández-Jalvo, Y., 1998, 101 uses for fossilized faeces, Nature, 393, 629-30.

Annour-Chelu, M., and Andrews, P., 1996, Surface modifications of bone, in The Experimental Earthw•rks Pr ject, 1960-1992 (ed. M. Bell), 178-85, Council for British Archaeology, York.

Behrensmeyer, A. K., 1978, Taphonomic and ecologic information on bone weathering, Pale bi logy, 4, $15 \bullet-62$.

Bell, L. S., Skinner, M. F., and Jones, S. J., 1996, The speed of pest mortem change to the human skeleton and its taphonomic significance, Forensic Science International, 82, 129-40.

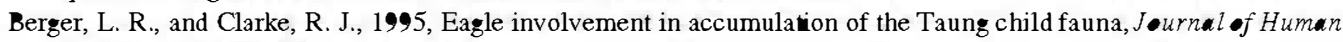
Ev•lution, 29, 275-99.

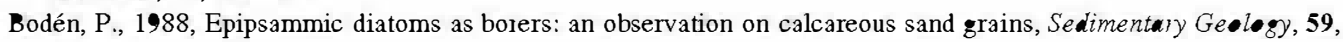
$143-7$.

Brain, C. K., 1981, The hunters or the hunted? University of Chicago Press, Chicago.

Bromage, T. G., 1985, Systematic inquiry in tests of negative/positive replica combinations for SEM, Journal of Micrescepy, 137, 209-16.

Brothwell, D., 1976, Further evidence of bone chewing by ungulates: the sheep of North Ronaldsay, Orkney, Journal of Archaelogical Science, 3, 179-82.

Child, A. M., and Pollard, A. M., 1990, Microbial attack on collagen, Archaemetry (Birkhäuser-Verlag, Basel), $617-25$

Crandall, B. C., and Stahl, P., 1995, Human digestive effects on a micromammalian skeleton, J urnal Archae logical Science, 22, 789-97.

Dauphin, Y., Denys, C., and Denis, A., 1988, Les mécanismes de formation des gisements de microvertébrés: modifications de la composition chimique élémentaire des os et dents de rongeurs issus de pelotes de régurgitation de rapaces, Comptes Rendus de l'Academie des Sciences, Paris, 307, série 2, 603-8.

Dauphin, Y., Denys, C., and Kowalski, K., 1997, Analysis of accumulation of rodent remains: role of the chemical composition of skeletal elements, Neues Jahrbuch für Gelogie und Paläntologie, Abhandlungen, 203(3), 295-315.

Davis, P. G., and Briggs, D. E. G., 1998, The impact of decay and disarticulation on the preservation of fossil birds, Palaios, 13, 3-13.

Denys, C., 1985, Nouveaux critères de reconnaissance des concentrations de microvertébrés d'après l'étude des pelotes de chouettes du Bostwana (Afrique australe), Bulletin du Museum National Histaire Naturelle, Paris, 7(4), 879-933.

Denys, C., Fernández-Jalvo, Y., and Dauphin, Y., 1995, Experimental taphonomy: preliminary results of the digestion of micromammal bones in the laboratory, Comptes Rendus de l'Academie des Sciences, Paris, 321, série II a, 803-9.

Denys, C., Williams, T., Dauphin, Y., Andrews, P., and Fernández-Jalvo, Y., 1996, Diagenetic changes in Pleistocene

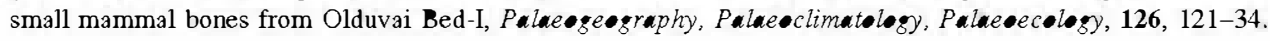


Diefenbach, C. O., 1975, Gastric function in Caiman crecedilus (Crocodylia: Reptilia), part I: rate of gastric digestion and $\mathrm{pH}$ and proteolysis, Comparative Biochemistry and Physiology, 51 A, 267-74.

Duke, G. E., Jegers, A. A., Loft, G., and Evanson, O. A., 1975, Gastric digestion in some systems, Comparaitve Biochemistry and Physiology, 50, 649-56.

Ellison, G. T. H., 1990, The effect of scavenger mutlation on insect succession at impala carcasses in southern Africa, Journal of Zeology, 220, 679-88.

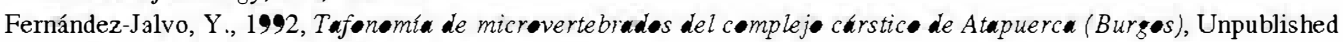
doctoral thesis, Universidad Complutense de Madrid.

Fernández-Jalvo, Y., 1995, Small mammal taphonomy at la Trinchera de Atapuerca (Burgos, Spain). A remarkable example of taphonomic criteria used for stratigraphic correlations and palaeoenvironmental interpretations, Palaegengiaphy, Palaeclimatology, Palaeveclogy, 114, 167-95.

Fernández-Jalvo, Y., and Andrews, P., 1992, Small mammal taphonomy of Gran Dolina, (Atapueıca, Burgos, Spain), Journal of Archae logical Science, 19, 407-28.

Fernández-Jalvo, Y., Denys, C., Andrews, P., Williams, T., and Dauphin, Y., 1998, Taphonomy and palaeoecology of Olduvai Bed-I (Pleistocene, Tanzania), J urnal of Human Ev•lutiøn, 34, 137-72.

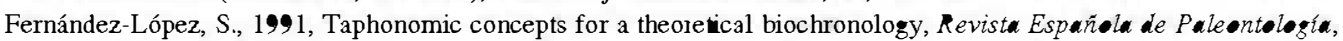
6(1), 37-49.

Fisher, D. C., 1981, Crocodilian scatology, microvertebrate concentrations, and enamel-less teeth, Pale bi॰l•gy, 7 , $262-75$.

Grupe, G., and Piepenbrink, H., 1989, Impact of microbial activity on trace element concentration in excavated bones, Applied Gechemistry, 4, 293-8.

Hackett, C. J., 1981, Microscopical focal destruction (tunnels) in excavated human bones, Medicine, Science and Law, 21, 243-65.

Haskell, N. H., Hall, R. D., Cervenka, V. J., and Clark, M. A., 1997, On the body: insect's life stage presence and their postmortem artefacts, in Forensic taph nomy: the postmortem of hum remains (eds. W. D. Haglung and M. H. Sorg), CRC Press, Boca Raton, Florida.

Haynes, G., 1983, A guide for differentiaing mammalian carnivore taxa responsible for gnaw damage to herbivore limb bones, Pale bi-logy, 9, 164-72.

Hedges, R. E. M., Millard, A. R., and Pike, A. W. G., 1995, Measurements and relationships of diagenetic alteration of bone from three archaeological sites, Journal of Archeological Science, 22, 201-9.

Hill, A., 1979, Disarticulation and scattering of mammal skeletons, Palebi-logy, 5, 261-74.

Laudet, F., and Fosse, P., 2001, Un assemblage d'os grignoté par les rongeurs au Paléogène (Oligocène supérieur, phosphorites du Queicy), Comptes Rendu de l'Academie des Sciences, Paris, 333, série II a, 195-200.

Marchiafava, V., Bonuci, L., and Ascenzi, A., 1974, Fungal osteoclasia: a model of dead bone resolption, Calcified Tissue Research, 14, 195-210.

Mayhew, D. F., 1977, Avian piedators as accumulators of fossil mammal material, Bereas, 6, 25-31.

Piepenbrink, H., 1989, Examples of chemical changes during fossilization, Applied Ge $\bullet$ chemistry, 4, 261-80.

Sanchez, V., Denys, C., and Fernández-Jalvo, Y., 1997, Origine et formation des accumulations de microvertébrés de la couche la du site du Monté di Tuda (Corse, Holocène). Contribution à l'étude taphonomique des micromammifères, Geodiversitas, 19(1), 129-57.

Selvaggio, M. M., and Wilder, J., 2001, Identifying the involvement of multiple carnivore taxa with archaeological bone assemblages, Journal of Archaelogical Science, 28, 465-70.

Sillen, A., 1992, Strontium-calcium ratios ( $\mathrm{Sr} / \mathrm{Ca}$ ) of Australøithecus robustus and associated fauna from Swartkrans, Journal of Human Evolution, 23, 495-516.

Sutcliffe, A. J., 1973, Similarity of bones and antlers gnawed by deer to human artefacts, Nature, 246, 428-30; reprinted in Deer (1974) 3, 270-2.

Tappen, M., 1994, Bone weathering in the tropical rain forest, Journal of Archaelogical Science, 21, 667-73.

Trueman, C. N., and Martill, D. M., 2002, The long-term survival of bone: the role of bioerosion, Archaemetry, 44, 000-000.

Tuross, N., Behrensmeyer, A. K., and Eans, E. D., 1989a, Strontum increases and crystallinity changes in taphonomic and archaeological bone, Journal of Archaelogical Science, 16, 661-72.

Tuross, N., Behrensmeyer, A. K., Eans, E. D., Fisher, L. W., and Hare, P. E., 1989b, Molecular preservation and crystallographic alterations in a weathering sequence of wildebeest bones, Applied Geechemistry, 4, 261-70.

Wedl, C., 1864, Uber einen im Zahnbein und Knochen keimenden Pilz. Akademi der Wissenschaften in Wien. Fitzungsbereichte Naturwissenschaftliche ABI. Mineralogi, biølogi erdkunde, 50, 171-93. 